Jurnal Teknologi Informasi dan Ilmu Komputer (JTIIK)

Vol. 2, No. 1, April 2015, hlm. 49-58

\title{
Penilaian Faktor Penerimaan Teknologi Blended learning di PTIIK Universitas Brawijaya dengan Metode Unified Theory of Acceptance and Use of Technology (UTAUT)
}

\author{
Fajar Pradana ${ }^{1}$, Aditya Rachmadi ${ }^{2}$, Fitra A. Bachtiar ${ }^{3}$ \\ ${ }^{1}$ Universitas Brawijaya \\ ${ }^{2}$ Universitas Brawijaya \\ ${ }^{3}$ Universitas Brawijaya
}

Email: $\underline{{ }^{1} \text { fajar.p@ub.ac.id }}, \underline{{ }^{2} \text { rachmadi.aditya@ub.ac.id }}, \underline{{ }^{3} \text { fitra.bachtiar@ub.ac.id }}$

(Naskah masuk: 29 Januari 2015, diterima untuk diterbitkan: 17 Februari 2015)

\begin{abstract}
Abstrak
Blended learning adalah kolaborasi atau kombinasi antara pembelajaran tradisional (pembelajaran dengan tatap muka secara langsung) dan pembelajaran menggunakan teknologi atau e-learning. Universitas Brawijaya sebagai penyelenggara pendidikan tinggi juga telah memfasilitasi penggunaan teknologi untuk blended learning. Namun pada penerapan blended learning masih terdapat beberapa permasalahan Pada penelitian ini digunakan Unified Theory of Acceptance and Use of Technology (UTAUT) sehingga mampu menutupi kekurangan dari penelitian sebelumnya. Faktor-faktor yang dapat diidentifikasi dengan UTAUT diwakili 2 faktor yaitu perilaku penggunaan (Use Behavior) serta perilaku keinginan dalam menggunakan sistem (Behavioral Intention). Masing-masing dari kedua faktor ini dipengaruhi oleh 4 faktor yaitu harapan kinerja sistem (performance expectancy), harapan usaha yang dikeluarkan untuk mengoperasikan sistem (Effort Expectancy), pengaruh sosial (Social Influence) serta kondisi fasilitas yang mendukung operasional sistem (Facilitating Conditions). Sedang 4 faktor ini ditentukan oleh gender, umur, pengalaman dalam menggunakan sistem kesukarelaan penggunaan sistem dari pengguna. Dengan menggunakan UTAUT ternyata didapatkan hasil evaluasi bahwa faktor-faktor yang memiliki pengaruh terhadap penggunaan sistem blended learning di PTIIK adalah H1 : Variabel-variabel PU, JF, RF, EA dan OE tidak berpengaruh terhadap variabel AT, H2 : Variabel-variabel PeoU berkontribusi terhadap variabel AT, H3 : SN, SF dan I tidak berkontribusi terhadap variabel AT, H4 : Variabel-variabel PBC/PB berkontribusi terhadap variabel IM, dan H5 : Variable AT mempengaruhi IM.
\end{abstract}

Kata kunci: Blended Learning,UTAUT, Universitas Brawijaya

\section{Abstract}

Blended learning is a collaboration or a combination of traditional learning (learning by direct face to face) and learning to use the technology or e-learning. UB as a provider of higher education has also facilitated the use of technology for blended learning. However, on the application of blended learning there are still some problems in this research used the Unified Theory of Acceptance and Use of Technology (UTAUT) so as to cover the lack of previous studies. Factors that can be identified by UTAUT represented by two factors, namely the usage behavior (Behavior Use) as well as the desire to use the system behavior (Behavioral Intention). Each of these two factors is influenced by four factors: the expectations of system performance (performance expectancy), the hope of effort expended to operate the system (Effort Expectancy), social influence (Social Influence) and the condition of the facilities that support the operation of the system (Facilitating Conditions). 4 of these factors being determined by gender, age, experience in using the voluntary system of use of the system from the user. By using UTAUT it was found on the evaluation that the factors that have an influence on the use of a system of blended learning in PTIIK is H1: Variables PU, JF, RF, EA and OE does not affect the variable AT, H2: Variables PEOU contribute to AT variables, H3: SN, SF and I do not contribute to the variable AT, H4: Variables PBC / PB contribute to variable IM, and H5: Variable AT affect IM

Keywords: Blended Learning,UTAUT, Brawijaya University

\section{PENDAHULUAN}

E-Learning merupakan salah satu penerapan teknologi di dalam proses pembelajaran terutama dalam pelaksanaan blended learning. Blended learning sendiri adalah kolaborasi atau kombinasi dalam proses pengajaran dengan didukung teknologi serta pembelajaran tradisional atau dengan tatap muka (Graham, 2006). Dari hasil penelitian yang dilakukan oleh $\mathrm{Oh}$ diketahui bahwa prosentase pembelajar memilih e-learning digabung dengan pembelajaran secara tradisional memiliki prosentase yang tinggi sekitar 64.4\% (Oh \& Park, 2009).Melihat hal ini dapat disimpulkan bahwa preferensi pembelajar di dalam menggunakan alat bantu pembelajaran terutama dengan bantuan teknologi digabung dengan pembelajaran tradisional memang cukup tinggi. 
Pemerintah dengan Permendikbud no. 24 tahun 2012 mendukung tentang penyelenggaraan pendidikan jarak jauh pada perguruan tinggi. Sesuai dengan aturan Permendikbud tentang pendidikan jarak jauh Universitas Brawijaya sebagai penyedia layanan pendidikan pada perguruan tinggi juga mendukung peraturan ini. Dukungan Universitas Brawijaya terhadap pendidikan jarak jauh pada perguruan tinggi dilaksanakan dengan mengharuskan tiap fakultas yang ada di dalamnya untuk menerapkan blended learning. PTIIK UB sebagai salah satu program setingkat fakultas, telah menggunakan teknologi blended learning sejak tahun ajaran 2011/2012 semester genap. Penerapan ini sekaligus sebagai jawaban dari PTIIK UB untuk mempersiapkan Pendidikan Jarak Jauh di masa mendatang. Penerapan blended learning di PTIIK UB dilaksanakan dengan menggunakan sistem elearningyang dirancang serta diimplementasikan melalui CMS Moodle.

Tentunya masih banyak faktor-faktor yang belum diketahui ketika PTIIK UB menerapkan elearning di dalam mendukung proses pengajaran yang dilakukan, diantaranya adalah kegagalan dalam menggunakan sistem. Pertanyaan lain yang muncul adalah apakah nantinya semua pembelajar serta mahasiswa yang menjadi subyek pengguna dari sistem akan menggunakan e-learning atau hanya sebagian yang menggunakannya? Apakah dengan menggunakan teknologi ini memang membantu dalam memacu pengguna untuk belajar? Selain hal di atas sangat sedikit penelitian yang membahas penggunaan e-learning sebagai salah satu alat pendukung dalam pengajaran (Pituch \& Lee, 2004). Dengan melihat permasalahan ini Bachtiar melakukan penelitian untuk mengetahui faktor-faktor apa yang sebenarnya mempengaruhi penggunaan dari e-learning, dari penelitian tersebut diketahui bahwa penggunaan e-learning ternyata dipengaruhi oleh faktor-faktor seperti kemudahan penggunaan sistem serta manfaat dari sistem (Bachtiar, 2013). Dari penelitian ini juga didapat beberapa permasalahan yang perlu dikaji lebih lanjut seperti pemilihan responden yang dapat mewakili seluruh pengguna dari sistem serta perlunya menggunakan metode yang lebih aktual.

Melihat dari permasalahan yang ada pada penelitian sebelumnya, penelitian ini dilaksanakan untuk menjawab kebutuhan yang telah dirumuskan di dalam penelitian yang telah dilakukan oleh Bachtiar. Tujuan dari penelitian ini adalah mengimplementasikan Unified Theory of Acceptance and Use of Technology (UTAUT) sebagai model dasar dalam penilaian faktor-faktor yang mempengaruhi penerimaan teknologi, penelitian ini juga dilakukan atas dasar kurangnya penenlitian di dalam yang mengkaji blended learning (Keller, Hrastinski, \& Carlsson, 2007), (Park, 2009), dan (Pituch \& Lee, 2004). Pemilihan UTAUT sebagai model penilaian penerimaan sistem dilakukan dengan lebih dulu mencari literatur tentang model yang dapat digunakan untuk menentukan faktor penerimaan teknologi. UTAUT sendiri merupakan adopsi dari beberapa model penerimaan teknologi seperti Theory of Reasoned Action (TRA), Technology of Acceptance Model (TAM), serta Social Cognitive Theory (SCT) (Venkatesh, 2003). UTAUT memiliki aturan dalam pemilihan responden yang didasarkan pada 4 kriteria yaitu umur, pengalaman menggunakan sistem, gender dan kemauan penggunaan dari sistem. Dibandingkan dengan TAM, UTAUT memiliki beberapa faktor yang memang tidak ada dalam faktor di dalam TAM yaitu faktor kondisi fasilitas yang penting untuk dikaji dalam penerapan $e$-learning.

\section{TINJAUAN PUSTAKA}

\subsection{Technology Acceptance Model (TAM)}

Technology Acceptance Model (TAM) pertama kali diciptakan oleh Davis (Davis, 1989), yang berdasar dari Theory of Reasoned Action (TRA) yang dikembangkan oleh Fishbein \& Ajzen pada tahun 1975 pada penelitian tentang psikologi. Secara umum bagan dari TRA dapat diilustrasikan pada Gambar 1 (Masrom, 2007).

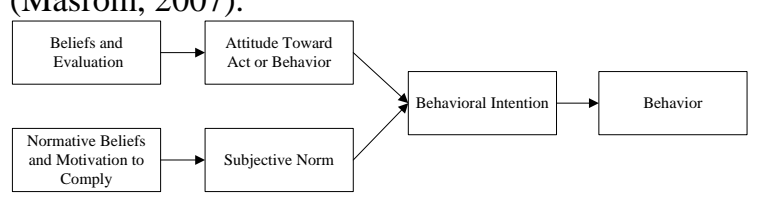

Gambar 1 Theory of Reasoned Action

Pada model TRA, dapat disimpulkan bahwa kepercayaan (beliefs) dan tindakan (behavior) dari setiap individu dipengaruhi oleh perilaku tujuan (intentional behavior). Sedangkan perilaku tujuan (behavioral intention) dipicu dari dua hal, yang pertama adalah sikap (attitude) terhdap perilaku dan yang kedua adalah norma subjektif (subjective norm) dari masing-masing individu (Masrom, 2007). TAM sampai hari ini masih terus dipelajari dan diperluas, ada dua peningkatan besar dalam metode pengukuran penerimaan teknologi yaitu TAM 2 (Venkatesh \& Davis 2000 \& Venkatesh 2000) dan Unified Theory of Acceptance and Use of Technology (atau UTAUT, Venkatesh et al. 2003). TAM 3 juga telah diusulkan (Venkatesh \& Bala 2008).

Berikut adalah model dari TAM:

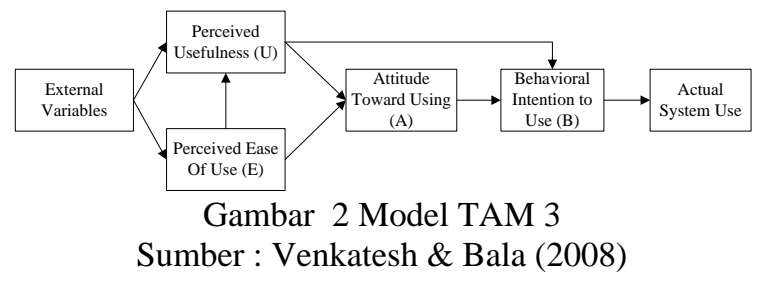

Beberapa peneliti telah mereplikasi studi dari Davis (Davis 1989) untuk memberikan bukti empiris antara 
hubungan yang ada yaitu kegunaan serta kemudahan penggunaan dengan penggunaan sistem (Adams, Nelson \& Todd 1992, Davis 1989, Hendrickson, Massey \& Cronan 1993; Segars \& Grover 1993; Subramanian 1994; Szajna 1994).

\subsection{Blended Learning}

Istilah blended learning banyak digunakan dalam bidang akademik maupun kalangan perusahaan. Istilah blended learning sering dikaitkan dengan sebuah teknologi yang sedang berkembang dalam dunia pendidikan seperti kutipan pada studi yang dilakukan oleh Graham (Graham, 2006) dalam The Journal of Asynchronous Learning Networks memperkirakan sebuah peningkatan dalam pembelajaran.

Blended learning adalah salah satu bentuk metode pembelajaran yang mempunyai dua bentuk (pembelajaran online dan konvensional). Disisi lain sudah terdapat pembelajaran langsung (tatap muka) yang telah di terapkan selama beberapa abad. Akan tetapi dengan berkembangnya teknologi disegala bidang, terutama dalam bidang pendidikan memungkinkan untuk mendistribusikan pembelajaran serta memungkinkan untuk berkomunikasi dan berinteraksi secara luas.

\subsection{Unified Theory Of Acceptance and Use of Technology (UTAUT)}

Unified Theory Of Acceptance and Use of Technology (UTAUT) menggunakan 4 faktor serta 4 hal yang dapat mempengaruhi penggunaan dari sebuah sistem. UTAUT dirancang oleh Venkatesh dengan membandingkan dan menggunakan faktorfaktor pada metode-metode yang digunakan untuk menentukan faktor yang dapat mempengaruhi penerimaan dari sebuah sistem. UTAUT dirancang dengan membandingkan antara beberapa metode yaitu Theory of Reasoned Action (TRA), Technology of Acceptance Model (TAM), Motivational Model (MM), Theory of Planned Behavior (TPB), Combined TAM dan TPB (C-TAM-TPB), Model of PC Utilization (MCPU), Innovation Diffusion Theory (IDT) serta Social Cognitive Theory (SCT). Dari perbandingan antara beberapa model ini didapatkan 4 faktor yang mempengaruhi penggunaan dari sistem. Penggunaan dari sistem diwakili 2 faktor yaitu perilaku penggunaan (Use Behavior) serta perilaku keinginan dalam menggunakan sistem (Behavioral Intention). Masing-masing dari kedua faktor ini dipengaruhi oleh 4 faktor yaitu harapan kinerja sistem (performance expectancy), harapan usaha yang dikeluarkan untuk mengoperasikan sistem (Effort Expectancy), pengaruh sosial (Social Influence) serta kondisi fasilitas yang mendukung operasional sistem (Facilitating Conditions). Sedang 4 faktor ini ditentukan oleh gender, umur, pengalaman dalam menggunakan sistem kesukarelaan penggunaan sistem dari pengguna (Venkatesh, 2003) seperti terlihat pada Gambar 3.

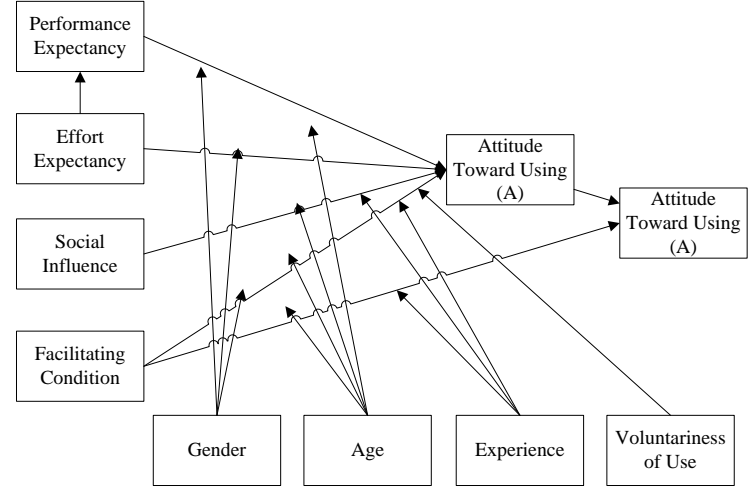

Gambar 3 Model UTAUT (Venkatesh, 2003)

\subsection{Penelitian Terkait}

Pada tahun 2013 Bachtiar melakukan penelitian untuk menganalisis faktor-faktor yang mempengaruhi penggunaan blended learning di PTIIK UB dengan menggunakan model TAM. Gambar 4 menunjukan model TAM hasil penelitian sebelumnya. Pada penelitian ini dikembangkan 4 hipotesis yang akan diujikan untuk mengetahui relasi antara faktor-faktor eksogenus Internet \& Computer Experience (ICE), Use of Supplementary Learning (USL), System Interactivity (SI), System Functionality $(S F)$, Usability $(U)$, Self Efficacy $(S E)$ dan Socio Environmental Factor(SEF) sebagai eksternal variabel (EV) dengan faktor-faktor endogen yaitu Perceive Usefulness, Perceive Ease of Use, Use of Supplementary Learning dan Use of Distance Learning.

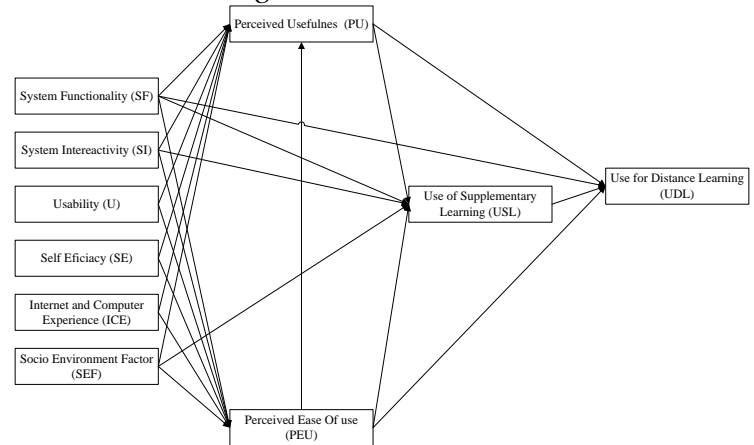

Gambar 4 Model TAM (Bachtiar, 2013)

Proses perancangan model dilakukan berdasarkan beberapa referensi penelitian dari TAM yang dilakukan oleh Davis, Tselios serta Pituch dan Lee. Setelah didapat perancangan model yang sesuai dengan hipotesis awal selanjutnya dilanjutkan dengan aktivitas perancangan kuesioner dari beberapa faktor endogen dan eksogen. Perancangan kuesioner didasarkan pada penelitian yang telah dilakukan oleh (Pituch dan Lee), (Sung Youl Park), (Davis (1989); Gefen and Straub (2000), (Tselios et. al.),. Data yang didapatkan selanjutnya dianalisis dengan menggunakan metode statistika deskriptif serta regresi linier untuk mengetahui relasi antara faktor satu dengan yang lain. Hasil analisa dari penelitian ini menyatakan bahwa Faktor-faktor yang berpengaruh terhadap UDL: 

a. USL terhadap UDL
$=0.430$
b. PU terhadap UDL
$=0.176$
c. PEU terhadap UDL
$=0.110$
d. SF terhadap UDL
$=0.152$

Faktor-faktor yang berpengaruh terhadap USL:
a. SF terhadap USL
$=-0.144$
b. PEU terhadap USL
$=0.170$
c. PU terhadap USL
$=0.558$
d. SI terhadap USL
$=0.081$
e. SEF terhadap USL
$=0.031$

Faktor-faktor yang berpengaruh terhadap PU:
a. SF terhadap PU
$=0.121$
b. SI terhadap PU
$=0.039$
c. U terhadap PU
$=0.132$
d. SE terhadap PU
$=0.047$
e. ICE terhadap PU
$=-0.046$
f. SEF terhadap PU
$=0.168$
g. PEU terhadap PU
$=0.433$

Faktor-faktor yang berpengaruh terhadap PEU:
a. SF terhadap PEU
$=0.163$
b. SI terhadap PEU
$=0.087$
$=0.227$
$=0.241$
$=0.054$
SE terhadap PEU
$=0.195$

Terdapat beberapa future works yang perlu dilengkapi pada penelitian selanjutnya diantaranya adalah kurangnya pemilihan responden dari segi umur, serta responden yang menjadi objek penelitian hanya responden dari pihak mahasiswa tetapi tidak diikutkan di dalam unsur penelitian ini responden dari pihak dosen, tidak adanya faktor yang menyatakan keadaan sarana dan prasarana yang mendukung blended learning. Melihat kekurangan pada penelitian sebelumnya maka peneliti mencoba menjawab kekurangan tersebut dengan menerapkan model UTAUT untuk mengetahui tingkat penerimaan dari teknologi blended learning. Dengan menggunakan model UTAUT ini diharapkan faktor-faktor yang sebelumnya menjadi kekurangan pada penelitian Bachtiar akan terjawab sehingga terbentuk suatu kesimpulan yang komprehensif mengenai penerimaan teknologi blended learning di PTIIK UB.

\section{METODE PENELITIAN}

Konsep penilaian penerimaan model teknologi adalah hal yang relatif baru bagi peneliti dan bagi lingkungan praktik PTIIK UB.Oleh karena itu penelitian ini lebih bersifat eksploratif untuk menggali manfaat dari kedua hal tersebut dan menggunakan pengembangan prototitpe untuk meningkatkan pemahaman terhadap masalah yang ada. Beberapa hal yang harus dijawab sudah dinyatakan dalam rumusan masalah dan diartikulasikan dalam tujuan penelitian. Aktivitasaktivitas utama yang dilakukan dalam penelitian ini meliputi:

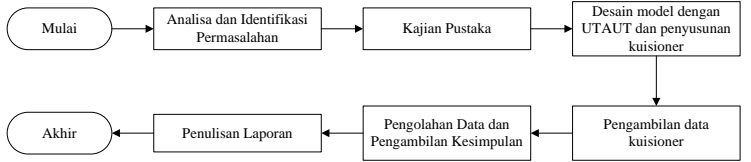

Gambar 5 Metode Penelitian

\section{Analisis dan Identifikasi Permasalahan}

Selain pengkajian terhadap kajian pustaka yang menjadi dasar keilmuan dalam melakukan penelitian, dalam tahapan ini juga dilakukan analisis awal. Analisis ini dimaksudkan sebagai tahapan untuk melakukan identifikasi permasalahan pada penerimaan e-learning untuk dapat dipakai sebagai fokus penelitian.

\section{Kajian Pustaka}

Pada tahapan ini dilakukan untuk mendapatkan justifikasi dan faktor yang mempengaruhi penerimaan teknologi e-learning di PTIIK. Untuk dapat mencapai tujuan ini, maka dalam tahapan ini akan dilakukan pengkajian terhadap teori-teori ataupun pemahaman secara mendetail tentang konsep penerimaan teknologi dan metode UTAUT. Permasalahan yang didapatkan pada tahap ini adalah implementasi TAM pada blended learning di PTIIK UB di penelitian sebelumnya ternyata memiliki future works yaitu kurangnya faktor dilihat dari sudut pandang fasilitas di organisasi serta tidak adanya pengaruh umur dalam pemilihan responden.

\section{Desain Model dengan UTAUT dan Penyusunan}

\section{Kuesioner}

Desain model sistem yang digunakan untuk implementasi penelitian dibangun dengan referensi dari metode UTAUT. Desain model ini dibangun dengan melihat pada faktor-faktor yang mempengaruhi penerimaan teknologi e-learning di PTIIK. Desain model UTAUT yang dibuat mengacu pada studi yang dilakukan oleh Venkatesh (Venkatesh, 2003).

Tahapan selanjutnya setelah mendesain model UTAUT adalah menyusun kerangka kuisioner. Pembuatan kerangka kuisioner dibuat berdasarkan dari model UTAUT yang telah di buat sebelumnya oleh Venkatesh. Responden yang dipilih adalah para dosen yang menggunakan e-learning dalam proses pembelajaran dengan jumlah 24 responden.

\section{HASIL DAN PEMBAHASAN \\ 4.1 Hasil Analisis Statistik Deskriptif}

Bagian ini memaparkan hasil analisis deskriptif setiap variabel yang diteliti dilihat dari beberapa aspek, yaitu skor minimum, skor maksimum, ukuran kecenderungan sentral, dan ukuran variabilitas data. Variabel-variabel yang dimaksud adalah Performance Expectancy (PE), Effort Expentancy $(E E)$, Social Influence (SE), Facilitating Condition $(F C)$, behavoiur intention (BI), dan Use behaviour (UB).

\section{Performance Expectancy}

Variabel Performance Expectancy mencakup sub-variabel berikut Perceived Usefulness, Extrinsic 
Motivation,Job-Fit, Relative Advantage, dan Outcome Expectation. Berikut adalah paparan data masing-masing sub variabel tersebut.

Performance Expectancy-Perceived Usefulness Hasil analisis data variabel perceived usefulness diringkas dan disajikan pada Tabel 1 berikut.

Tabel 1. Ringkasan Hasil Analisis Variabel perceived usefulness

\begin{tabular}{|c|c|}
\hline $\begin{array}{c}\text { Statistics } \\
\text { RPU }\end{array}$ & \\
\hline $\begin{array}{l}\quad \mathrm{N} \\
\text { Mean } \\
\text { Median } \\
\text { Std. Deviation } \\
\text { Skewness } \\
\text { Std. Error of Skewness } \\
\text { Kurtosis } \\
\text { Std. Error of Kurtosis } \\
\text { Range } \\
\text { Minimum } \\
\text { Maximum }\end{array}$ & $\begin{array}{c}24 \\
0 \\
3,7567 \\
3,6700 \\
, 43618 \\
-, 278 \\
, 472 \\
-, 678 \\
, 918 \\
1,50 \\
3,00 \\
4,50\end{array}$ \\
\hline
\end{tabular}

Hasil analisis statistik deskriptif menunjukkan bahwa sebagian besar responden cenderung netral bahwa sistem e-learning dapat meningkatkan performa pekerjaan dan meningkatkan efektifitas pekerjaan. Hal ini dapat dilihat dari rerata data yang menunjukkan 3,7 dari nilai maksimum pada faktor perceived usefulness, yaitu 5, dan nilai minimumnya, yaitu 1.

\section{Effort Expectancy}

Variabel Effort Expectancy mencakup sub-variabel berikut Perceived Ease Of Use, dan Complexity. Berikut adalah paparan data masing-masing sub variabel tersebut.

\section{Effort Expectancy - Perceived Ease Of Use}

$$
\text { (PEoU) }
$$

Hasil analisis data variabel PeOE diringkas dan disajikan pada Tabel 2 berikut.

Tabel 2. Ringkasan Hasil Analisis Variabel PEoU

\section{Statistics}

\begin{tabular}{|l|r|} 
RPEoU \\
\hline $\mathrm{N} \quad$ Valid & 24 \\
Mean $\quad$ Missing & 0 \\
Median & 3,5388 \\
Std. Deviation & 3,4400 \\
Skewness &, 52894 \\
Std. Error of Skewness &, 497 \\
Kurtosis &, 472 \\
Std. Error of Kurtosis &,- 096 \\
Range &, 918 \\
Minimum & 2,12 \\
Maximum & 2,63 \\
\hline
\end{tabular}

Effort Expectancy - Complexity $(C)$

Hasil analisis data variabel Com diringkas dan disajikan pada Tabel 3 berikut.

Tabel 3. Ringkasan Hasil Analisis Variabel C

RCOM
\begin{tabular}{|l|r|}
\hline N $\quad$ Valid & 24 \\
Mean $\quad$ Missing & 0 \\
Median & 2,7083 \\
Std. Deviation & 2,7500 \\
Skewness &, 64969 \\
Std. Error of Skewness &, 345 \\
Kurtosis &, 472 \\
Std. Error of Kurtosis &,- 539 \\
Range &, 918 \\
Minimum & 2,50 \\
Maximum & 1,75 \\
\hline
\end{tabular}

\section{Social Influence}

Variabel Social Infulence mencakup sub-variabel berikut Subjective Norm, Image, dan Social factor. Berikut adalah paparan data masing-masing sub variabel tersebut.

\section{Social Influence - Subjective Norm (SN)}

Hasil analisis data variabel Sn diringkas dan disajikan pada Tabel 4 berikut.

Tabel 4. Ringkasan Hasil Analisis Variabel SN

\section{Statistics}

\begin{tabular}{|l|r|} 
RSN & \multicolumn{2}{|c|}{ Valid } \\
N $\quad$ Missing & 24 \\
Mean & 3,0417 \\
Median & 3,0000 \\
Std. Deviation &, 69025 \\
Skewness &,- 919 \\
Std. Error of Skewness &, 472 \\
Kurtosis & 2,522 \\
Std. Error of Kurtosis &, 918 \\
Range & 3,00 \\
Minimum & 1,00 \\
Maximum & 4,00 \\
\hline
\end{tabular}

\section{Facilitating Condition}

Variabel Facilitating Condition mencakup subvariabel berikut Perceived Behavioral Control, Facilitating Condition, dan Comptability. Berikut adalah paparan data masing-masing sub variabel tersebut

\section{Facilitating Condition - Perceived Behavioral Control (PBC)}

Hasil analisis data variabel PBC diringkas dan disajikan pada Tabel 5 berikut.

Tabel 5. Ringkasan Hasil Analisis Variabel PBC

\section{Statistics}

\begin{tabular}{|l|r|} 
RI & \multicolumn{2}{c|}{ Valid } \\
N $\quad$ Missing & 0 \\
Mean & 2,6533 \\
Median & 2,6700 \\
Std. Deviation &, 60170 \\
Skewness &, 403 \\
Std. Error of Skewness &, 472 \\
Kurtosis &,- 634 \\
Std. Error of Kurtosis &, 918 \\
Range & 2,00 \\
Minimum & 2,00 \\
Maximum & 4,00 \\
\hline
\end{tabular}


Attitude Toward Using Technology

Variabel Attitude Toward Using Technology mencakup sub-variabel berikut Attitude toward Behavior dan Intrinsic Motivation. Berikut adalah paparan data masing-masing sub variabel tersebut

\section{Attitude Toward Using Technology - Attitude toward Behavior (AT)}

Hasil analisis data variabel AT diringkas dan disajikan pada Tabel 6 berikut.

Tabel 6. Ringkasan Hasil Analisis Variabel AT

\section{Statistics}

\begin{tabular}{|l|r|}
\hline RAT & \\
\hline N $\quad$ Valid & 24 \\
Mean $\quad$ Missing & 0 \\
Median & 2,9717 \\
Std. Deviation & 3,0000 \\
Skewness &, 50937 \\
Std. Error of Skewness &,- 484 \\
Kurtosis &, 472 \\
Std. Error of Kurtosis &, 205 \\
Range &, 918 \\
Minimum & 2,00 \\
Maximum & 2,00 \\
\end{tabular}

\subsection{Hasil Analisis Jalur}

Desain model sistem yang digunakan untuk implementasi penelitian dibangun dengan referensi dari metode UTAUT. Desain model ini dibangun dengan melihat pada faktor-faktor yang mempengaruhi penerimaan teknologi e-learning di PTIIK. Desain model UTAUT yang dibuat mengacu pada studi yang dilakukan oleh Venkatesh (Venkatesh, 2003).

Tujuan lain dari penelitian ini adalah menguji hipotesis yang telah di rumuskan. Berikut adalah hipotesis yang akan dibuktikan :

\section{Analisis hipotesis 1 : Variabel-variabel PU, JF, RF, EA dan OE berkontribusi terhadap variabel AT.}

Variabel AT adalah variabel indogen, yaitu variabel yang dipengaruhi oleh variabel-variabel eksogen, sedangkan variabel-variabel PU, JF, RF, EA dan OE adalah variabel eksogen. Persamaan struktural pada konstelasi ini adalah sebagai berikut:

$$
\begin{aligned}
& \text { Persamaan regresinya adalah } \mathrm{AT}=\beta \mathrm{PU}+\beta \mathrm{JF}+\beta \\
& \mathrm{RF}+\beta \mathrm{EA}+\beta \mathrm{OE}+\varepsilon
\end{aligned}
$$

Hasil analisis regresi antara variabel UDL dengan variabel-variabel PU, JF, RF, EA dan OE dipaparkan pada Tabel 16 berikut ini.

Tabel 7 Hasil analisis regresi antara variabel AT dengan variabel-variabel PU, JF, RF, EA dan OE

\section{Coefficients}

\begin{tabular}{|l|r|r|r|r|r|}
\hline Model & \multicolumn{2}{|c|}{$\begin{array}{c}\text { Unstandardized } \\
\text { Coefficients }\end{array}$} & $\begin{array}{c}\text { Standardized } \\
\text { Coefficients }\end{array}$ & \multirow{2}{*}{$\mathrm{t}$} & \multirow{2}{*}{ Sig. } \\
\cline { 2 - 4 } & \multicolumn{1}{c|}{$\mathrm{B}$} & $\begin{array}{c}\text { Std. } \\
\text { Error }\end{array}$ & \multicolumn{1}{|c|}{ Beta } & & \\
\hline (Constant) & .301 & 1.164 & & .259 & .799 \\
PU's & .350 & .248 & .383 & 1.414 & .174 \\
EM's & -.048 & .186 & -.059 & -.260 & .798 \\
JF's & .435 & .300 & .347 & 1.449 & .165 \\
RA's & .109 & .285 & .119 & .382 & .707 \\
OE's & -.059 & .232 & -.063 & -.252 & .804 \\
\hline
\end{tabular}

Dependent Variable: AT's

a. Dependent Variable: AT's

Hasil analisis data sebagaimana dipaparkan pada Tabel 4.11 di atas nilai beta $(\beta)$ masing-masing variabel PU, JF, RF, EA dan OE ditunjukkan oleh nilai pada kolom Standardized Coefficients Beta, yaitu PU $(\beta=0.383), \operatorname{EM}(\beta=-0.059), \mathrm{JF}(\beta=0.347)$, RA $(\beta=0.119)$, dan OE $(\beta=-0.063)$. Dari hasil analisa regresi yang telah dilakukan didapati seluruh variabel yang memiliki nilai Sig. lebih dari nilai pvaluenya (Sig.) atau lebih kecil dari 0.05 . Ini berarti bahwa, jalur AT dengan masing-masing variabel PU, JF, RA, EM dan OE adalah tidak signifikan.

Sedangkan nilai $\mathrm{p} \square==0,846$. Secara visual jalur antara variabel AT dengan variabel-variabel PU, EM, JF, RA dan OE dapat ditunjukkan oleh diagram jalur sebagaimana tertuang pada Gambar 7 di bawah ini.

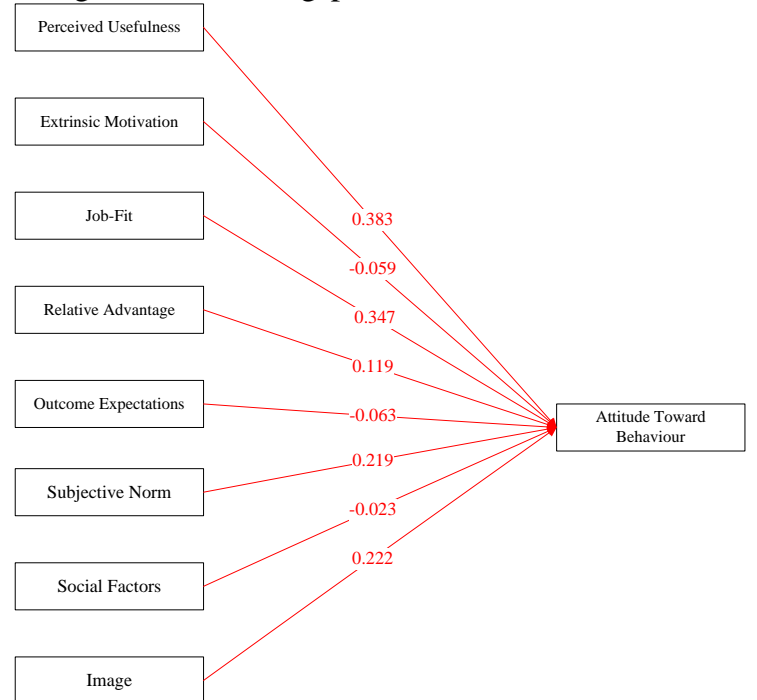

Gambar 6. Jalur antara variabel-variabel PU, JF, RF, EA dan OE terhadap variabel AT

Berdasarkan Gambar 6 secara umum dapat dinyatakan bahwa semua faktor yaitu PU, JF, RA berpengaruh terhadap AT sedangkan variabel atau faktor EM dan OE tidak berpengaruh terhadap variabel AT. Kontribusi masing-masing faktor yaitu Skor PU $(\beta=0.383), \mathrm{EM}(\beta=-0.059), \mathrm{JF}(\beta=0.347)$, RA $(\beta=0.119)$, dan OE $(\beta=-0.063)$; sedangkan nilai constantnya adalah 0.301. Keseluruhan model hipotesis 1 dapat di tunjukkan dalam notasi matematik regresi pada persamaan (1) berikut ini: 


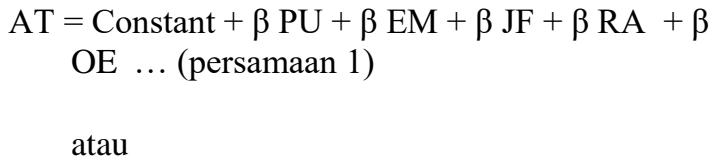

Persamaan tersebut di atas dapat diinterpretasikan bahwa kontribusi total variabel eksogen (PU, JF, RF, EA dan OE) terhadap variabel indogen (AT) adalah sebesar: $0.383-0.059+0.347+0.119-0.063$ yaitu sebesar 0,727 . Variabel-variabel ini tidak signifikan mempengaruhi AT.

\section{Analisis hipotesis 2 : Variabel-variabel PEoU, Com berkontribusi terhadap variabel AT.}

Pada konstelasi ini, variabel AT adalah variabel endogen, yaitu variabel yang dipengaruhi oleh variabel-variabel eksogen, sedangkan variabelvariabel PEoU dan Com dalah variabel eksogen. Persamaan struktural pada konstelasi ini adalah sebagai berikut:

Persamaan regresinya adalah $\mathrm{AT}=\beta \mathrm{PEoU}+\beta$ Com

$$
+\varepsilon
$$

Hasil analisis regresi antara PEoU dan Com terhadap variabel AT dipaparkan pada Tabel 8 berikut ini.

Tabel 8 Hasil Analisis Regresi antara Variabel AT dengan Variabel-Variabel PEoU dan Com

\section{Coefficients $^{\mathrm{a}}$}

\begin{tabular}{|c|c|c|c|c|c|}
\hline \multirow[t]{2}{*}{ Model } & \multicolumn{2}{|c|}{$\begin{array}{l}\text { Unstandardized } \\
\text { Coefficients }\end{array}$} & $\begin{array}{l}\text { Standardized } \\
\text { Coefficients }\end{array}$ & \multirow[t]{2}{*}{$t$} & \multirow[t]{2}{*}{ Sig. } \\
\hline & B & $\begin{array}{l}\text { Std. } \\
\text { Error }\end{array}$ & Beta & & \\
\hline (Constant) & .608 & .954 & & .637 & .531 \\
\hline${ }_{1}$ PEoU's & .516 & .197 & .536 & 2.623 & .016 \\
\hline Com's & .199 & .160 & .254 & 1.242 & .228 \\
\hline
\end{tabular}

a. Dependent Variable: AT's

a. Dependent Variable: AT's

Hasil analisis data sebagaimana dipaparkan pada Tabel 8

di atas nilai beta $(\beta)$ masing-masing variabel PEoU dan Com ditunjukkan oleh nilai pada kolom Standardized Coefficients Beta, yaitu PEoU ( $\beta=$ 0.536) dan Com $(\beta=0.254)$. Karena nilai $p$ value(Sig.) dari variabel PEoU lebih kecil dari 0,05. Ini berarti bahwa, keterkaitan antara jalur PEoU terhadap AT adalah signifikan. Sedangkan keterkaitan antara variabel AT dan Com tidaklah signifikan. Sedangkan nilai $\mathrm{p} p \varepsilon=\sqrt{1-R^{2}}=$ $\sqrt{1-0,499}=$ Secara visual jalur antara variabel USL dengan masing-masing variabel PEoU dan Com dapat ditunjukkan oleh diagram jalur sebagaimana tertuang pada Gambar 8 di bawah ini.

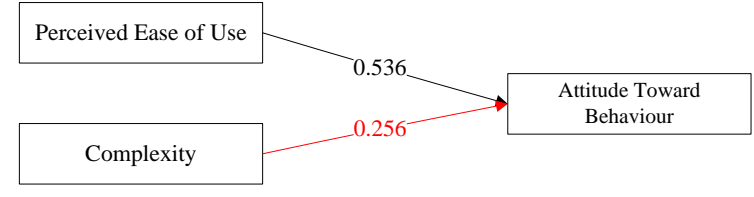

Gambar 7 Jalur antara variable PEoU, Com terhadap variabel AT

Berdasarkan Gambar 7 secara umum dapat dinyatakan bahwa variabel SF, PEU, dan PU berpengaruh terhadap USL. Kontribusi masingmasing faktor adalah PEoU $(\beta=0.536)$ dan Com $(\beta$ $=0.254)$; sedangkan nilai constantnya adalah 0,608. Model hipotesis 2 dapat di tunjukkan dalam notasi matematik regresi pada persamaan (2) berikut ini:

$\mathrm{UDL}=$ Constant $+\beta$ PEoU

... (persamaan 2$)$

atau

$\mathrm{UDL}=0,608+0.536 \mathrm{Com}$

Persamaan tersebut di atas dapat diinterpretasikan bahwa kontribusi total variabel eksogen (PEoU) terhadap variabel indogen (AT) adalah sebesar: 0.536 .

Analisis hipotesis 3 : Variabel-variabel SN, SF dan I berkontribusi terhadap variabel $\mathrm{AT}$

Variabel AT adalah variabel endogen, yaitu variabel yang dipengaruhi oleh variabel-variabel eksogen. Sedangkan variabel-variabel SN, SF dan I adalah variabel eksogen. Persamaan struktural pada konstelasi ini adalah sebagai berikut:

Persamaan regresinya adalah $\mathrm{AT}=$ Constant $+\beta \mathrm{SN}$ $+\beta \mathrm{SF}+\beta \mathrm{I}+\varepsilon$

Hasil analisis regresi antara variabel AT dengan variabel-variabel SN, SF dan I dipaparkan pada Tabel 9 berikut ini.

Tabel 9 Hasil analisis regresi antara variabel AT dengan variabel-variabel SN, SF dan I.

Coefficients ${ }^{a}$

\begin{tabular}{|l|r|r|r|r|r|}
\hline Model & \multicolumn{2}{|c|}{$\begin{array}{c}\text { Unstandardized } \\
\text { Coefficients }\end{array}$} & $\begin{array}{c}\text { Standardize } \\
\text { d } \\
\text { Coefficients }\end{array}$ & \multirow{2}{*}{ t } & \multirow{2}{*}{ Sig. } \\
\cline { 2 - 4 } & \multicolumn{1}{|c|}{ B } & \multicolumn{1}{c|}{$\begin{array}{c}\text { Std. } \\
\text { Error }\end{array}$} & Beta & & \\
\hline (Constant) & 2.046 & .803 & & 2.548 & .019 \\
SN's & .167 & .170 & .219 & .983 & .337 \\
SF's & -.022 & .247 & -.023 & -.090 & .929 \\
l's & .188 & .206 & .222 & .914 & .371 \\
\hline
\end{tabular}

a. Dependent Variable: $A T$ 's

Hasil analisis data sebagaimana dipaparkan pada Tabel 9 di atas nilai beta $(\beta)$ masing-masing variabel SN, SF dan I ditunjukkan oleh nilai pada kolom Standardized Coefficients Beta, yaitu SN ( $\beta=$ $0.219)$, SF $(\beta=-0.023)$, dan I $(\beta=0.222)$ yang masing-masing memiliki nilai p-valuenya (Sig.) lebih kecil dari 0.05. Ini berarti bahwa, jalur AT dengan masing-masing variabel SN, SF dan I adalah tidak signifikan. Secara visual jalur antara variabel AT dengan variabel-variabel SN, SF dan I dapat 
ditunjukkan oleh diagram jalur sebagaimana tertuang pada Gambar 9 di bawah ini.

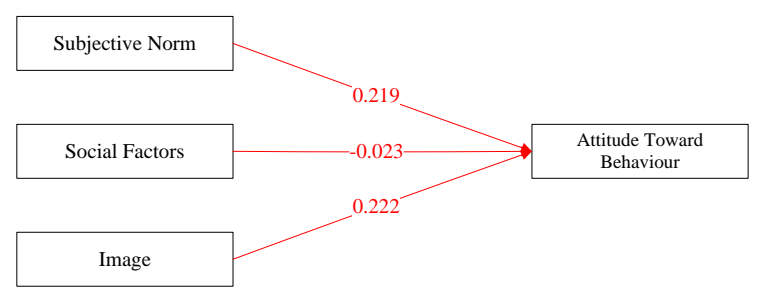

Gambar 8. Jalur antara variabel SN, SF dan I terhadap variabel AT

Berdasarkan Gambar 8 dapat dinyatakan bahwa secara umum faktor SN, SF dan I berpengaruh terhadap AT. Kontribusi masing-masing faktor yaitu Skor $\beta$ SN $(\beta=0,219)$, Skor $\beta$ SF $(\beta=-0,023)$ dan Skor $\beta$ I $(\beta=0,222)$; sedangkan nilai constantnya adalah 2.046. Keseluruhan model hipotesis 3 dapat di tunjukkan dalam notasi matematik regresi pada persamaan (3) berikut ini:

$\mathrm{AT}=$ Constant $+\beta \mathrm{SN}+\beta \mathrm{SF}+\beta \mathrm{I} \ldots$ (persamaan 3) atau

$\mathrm{AT}=2,046+0,219 \mathrm{SN}+(-0,023) \mathrm{SF}+0,222 \mathrm{I}$

Persamaan tersebut di atas dapat diinterpretasikan bahwa kontribusi total variabel eksogen (SN, SF dan I) terhadap variabel indogen (AT) adalah sebesar: 0,219 + -0,023 + 0,222, yaitu sebesar 0,418. Tetapi ketiga variabel ini tidak signifikan mempengaruhi variabel AT.

\section{Analisis hipotesis 4 : Variabel-variabel PBC/PB dan FC berkontribusi terhadap variabel IM}

Pada konstelasi ini, variabel IM adalah variabel indogen, yaitu variabel yang dipengaruhi oleh variabel-variabel eksogen, sedangkan variabelvariabel PBC/PB dan FC adalah variabel eksogen. Persamaan struktural pada konstelasi ini adalah sebagai berikut:

Persamaan regresinya adalah $\mathrm{IM}=$ Constant $+\beta$

$\mathrm{PBC} / \mathrm{PB}+\beta \mathrm{FC}+\varepsilon$

Hasil analisis regresi antara $\mathrm{PBC} / \mathrm{PB}$ dan FC terhadap variabel IM dipaparkan pada Tabel 10 berikut ini.

Tabel 10 Variabel-variabel PBC/PB dan FC berkontribusi terhadap variabel IM

Coefficients $^{a}$

\begin{tabular}{|c|c|c|c|c|c|}
\hline \multirow[t]{2}{*}{ Model } & \multicolumn{2}{|c|}{$\begin{array}{l}\text { Unstandardized } \\
\text { Coefficients }\end{array}$} & $\begin{array}{c}\text { Standardized } \\
\text { Coefficients }\end{array}$ & \multirow[t]{2}{*}{$\mathrm{t}$} & \multirow[t]{2}{*}{ Sig. } \\
\hline & $B$ & $\begin{array}{l}\text { Std. } \\
\text { Error }\end{array}$ & Beta & & \\
\hline (Constant) & .362 & .871 & & .415 & .682 \\
\hline 1 PB's & .683 & .204 & .571 & 3.348 & .003 \\
\hline FC's & .194 & .134 & .247 & 1.449 & .162 \\
\hline
\end{tabular}

Hasil analisis data sebagaimana dipaparkan pada Tabel 10 di atas nilai beta $(\beta)$ masing-masing variabel PBC/PB dan FC ditunjukkan oleh nilai pada kolom Standardized Coefficients Beta, yaitu PBC/PB ( $\beta=$ 0.571), FC $(\beta=0.247)$. Namun masing-masing memiliki nilai p-valuenya (Sig.) yang berbeda. Nilai p-value (Sig.) dari jalur PBC/PB dan IM lebih kecil dari 0.05. Ini berarti bahwa, jalur IM dengan variabel PBC/PB adalah signifikan. Sedangkan jalur IM dengan variabel FC tidak signifikan.

Sedangkan nilai $p \varepsilon=\sqrt{1-R^{2}}=\sqrt{1-0,317}=$ 0,681. Secara visual jalur antara variabel IM dengan masing-masing variabel $\mathrm{PBC} / \mathrm{PB}$ dan $\mathrm{FC}$ dapat ditunjukkan oleh diagram jalur sebagaimana tertuang pada Gambar 10 di bawah ini.

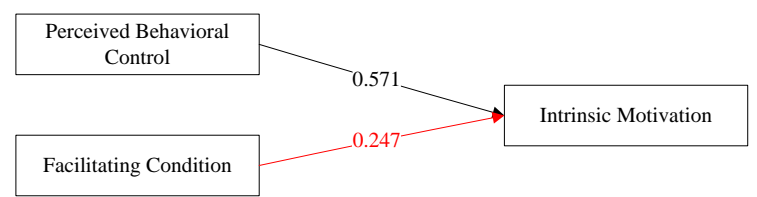

Gambar 9. Jalur antara Variabel-variabel PBC/PB dan FC terhadap variabel IM

Deskripisi singkat:

Secara umum variabel PBC/PB dan FC berpengaruh terhadap IM. Kontribusi masing-masing faktor adalah PBC/PB $(\beta=0,571)$ dan FC $(\beta=0.247)$; sedangkan nilai constantnya adalah 0,362 . Model hipotesis 4 dapat di tunjukkan dalam notasi matematik regresi pada persamaan (4) berikut ini:

$\mathrm{IM}=$ Constant $+\beta \mathrm{PBC} / \mathrm{PB} \quad \ldots$ (persamaan 4$)$ atau

$\mathrm{IM}=0,362+0,571 \mathrm{PBC} / \mathrm{PB}$

Persamaan tersebut di atas dapat diinterpretasikan bahwa kontribusi total variabel eksogen (PBC/PB) terhadap variabel indogen (PEU) adalah sebesar: 0,571

\section{Analisis hipotesis 5 : Variabel AT berkontribusi terhadap variabel IM}

Pada konstelasi ini, variabel IM adalah variabel endogen, yaitu variabel yang dipengaruhi oleh variabel-variabel eksogen, sedangkan variabelvariabel $\mathrm{PBC} / \mathrm{PB}$ dan FC adalah variabel eksogen. Persamaan struktural pada konstelasi ini adalah sebagai berikut:

Persamaan regresinya adalah $\mathrm{IM}=$ Constant $+\beta$ AT
$\quad+\varepsilon$

Hasil analisis regresi antara AT terhadap variabel IM dipaparkan pada Tabel 11 berikut ini. 
Tabel 11 Hasil analisis regresi antara variabel IM dengan variabel-variabel AT.

Coefficients $^{a}$

\begin{tabular}{|l|r|r|r|r|r|}
\hline Model & \multicolumn{2}{|c|}{$\begin{array}{c}\text { Unstandardized } \\
\text { Coefficients }\end{array}$} & $\begin{array}{c}\text { Standardized } \\
\text { Coefficients }\end{array}$ & \multirow{2}{*}{ Sig. } \\
\cline { 2 - 4 } & \multicolumn{1}{|c|}{$\begin{array}{c}\text { Std. } \\
\text { Error }\end{array}$} & Beta & & \\
\hline 1 (Constant) & 1,844 &, 563 & & 3,277 &, 003 \\
AT's &, 557 &, 187 &, 537 & 2,985 &, 003 \\
\hline
\end{tabular}

Hasil analisis data sebagaimana dipaparkan pada Tabel 11 di atas nilai beta $(\beta)$ variabel AT ditunjukkan oleh nilai pada kolom Standardized Coefficients Beta, yaitu AT ( $\beta=0.537)$. Nilai p-value(Sig.) dari jalur AT lebih kecil dari 0.05. Ini berarti bahwa, jalur IM dengan variabel AT memiliki korelasi signifikan. Secara visual jalur antara variabel IM dengan variabel AT dapat ditunjukkan oleh diagram jalur sebagaimana tertuang pada Gambar 4.27 di bawah ini.

\begin{tabular}{|c|c|c|}
\hline $\begin{array}{c}\text { Attitude Toward } \\
\text { Behaviour }\end{array}$ & $\longrightarrow$ Intrinsik Motavation \\
\cline { 3 - 3 } & & \\
\hline
\end{tabular}

Gambar 10. Jalur antara Variabel AT berkontribusi terhadap variabel IM

Deskripisi singkat:

Secara umum variabel AT berpengaruh terhadap IM. Kontribusi faktor adalah AT $(\beta=0,537)$; sedangkan nilai constantnya adalah 1,844 . Model hipotesis 5 dapat di tunjukkan dalam notasi matematik regresi pada persamaan (5) berikut ini:

$\mathrm{IM}=$ Constant $+\beta \mathrm{AT}$

...(persamaan 5)

atau

$\mathrm{IM}=1,844+0,537 \mathrm{AT}$

Persamaan tersebut di atas dapat diinterpretasikan bahwa kontribusi total variabel eksogen (AT) terhadap variabel endogen (IM) adalah sebesar: 0,537 .

\section{Hasil Model Analisa}

Dari hasil model parsial diatas didapatkan sebuah model awal dengan jalur dengan masing-masing kontribusinya terhadap variabel lain. Model awal ini adalah model analisa yang dirumuskan pada awal penelitian. Akan tetapi model ini setelah dianalisa secara parsial secara bertahap terdapat beberapa variabel yang tidak berpengaruh/mempunyai korelasi yang rendah terhadap variabel yang ditandai dengan jalur yang berwarna merah seperti ditunjukan pada Gambar 11.

Dari hasil analisis terlihat pada Gambar 11 bahwa variabel endogen terhadap variabel eksogen yaitu $P U, E M, J F, R A, O E$ tidak mempengaruhi variabel endogen yaitu Attitude toward Behavior. Karena memiliki nilai significance lebih dari 0,05 seperti terlihat pada tabel 7. Hal ini dikarenakan ketika digunakan oleh dosen, $l$ oad dari $e$ - learning tidak dalam keadaan yang tinggi, karena dosen hanya memanfaatkan fitur-fitur dasar dari elearning yang tidak membutuhkan load yang tinggi dari sistem. Misalkan dosen hanya mengakses fitur upload materi pada jam-jam yang tidak memiliki load sistem tinggi (contohnya pada jam istirahat) dibanding mahasiswa. Selain itu dosen lebih memilih sistem lain seperti blog dosen dan dropbox karena beranggapan unjuk kerja dari e-learning kurang maksimal dan tidak memberikan dampak yang signifikan terhadap kemudahan dalam proses belajar mengajar.

Dari hasil analisis dari variabel endogen yaitu $\mathrm{PeOU}$ mempengaruhi variabel endogen yaitu $A T$ nilai (significance $<0,05$ ) sedangkan variabel eksogen Complexity (Com) dari sistem tidak mempengaruhi variabel endogen Attitude toward AT. Kompleksitas tidak berpengaruh terhadap penggunaan karena dosen-dosen dari PTIIK UB dapat mengerti dan memahami fitur-fitur kompleks dari e-learning tersebut sehingga tidak perlu dilakukan training atau pelatihan untuk menggunakan sistem itu, tetapi dosen merasa bahwa sistem e-learning dirasa tidak user friendly, sehingga sistem ini tidak memberikan kemudahan dalam berinteraksi seperti peletakan menu dan tombol yang kurang familiar bagi dosen.

Hasil analisis dari variabel endogen yaitu Social $S F, S N$ dan I terhadap variabel eksogen Attitude Toward Behavior AT. Karena dengan menggunakan e-learning dosen-dosen percaya tidak akan meningkatkan image terhadap rekan sejawatnya serta faktor sosial seperti keberadaan rekan-rekan yang menggunakan e-learning tidak serta merta membuat rekan dosen yang lain menggunakan sistem ini.

Hasil analisis dari variabel eksogen Perceive Behavior Control (PBC) berpengaruh terhadap variabel endogen Intrinsic Motivation (IM) sedang Facilitating Condition ( $F C$ ) tidak berpengaruh. Motivasi dari dosen dalam menggunakan e-learning ternyata tidak dipengaruhi oleh adanya petunjuk dalam menggunakan e-learning hal ini disebabkan karena dosen telah mampu untuk mengoperasikan elearning tanpa melalui pelatihan terlebih dahulu. Tetapi ternyata motivasi dosen dalam menggunakan e-learning dipengaruhi oleh sistem ini yang tidak kompatibel dengan sistem yang ada di PTIIK UB seperti SIAM dan SIADO untuk mencatat nilai sehingga menyebabkan motivasi dalam menggunakan e-learning akan turun.

Hasil analisis dari variabel eksogen Attitude toward Behavior (AtB) mempengaruhi Intrinsic Motivation (IM). Secara umum perilaku dalam menggunakan e-learning ternyata mempengaruhi motivasi penggunaan, hal ini dikarenakan bahwa perilaku dari penggunaan sistem tidak dipengaruhi oleh fasilitas serta keadaan sosial tetapi murni dari keinginan dan motivasi seseorang dalam menggunakan sistem pembelajaran blended learning dengan e-learning (moodle). 


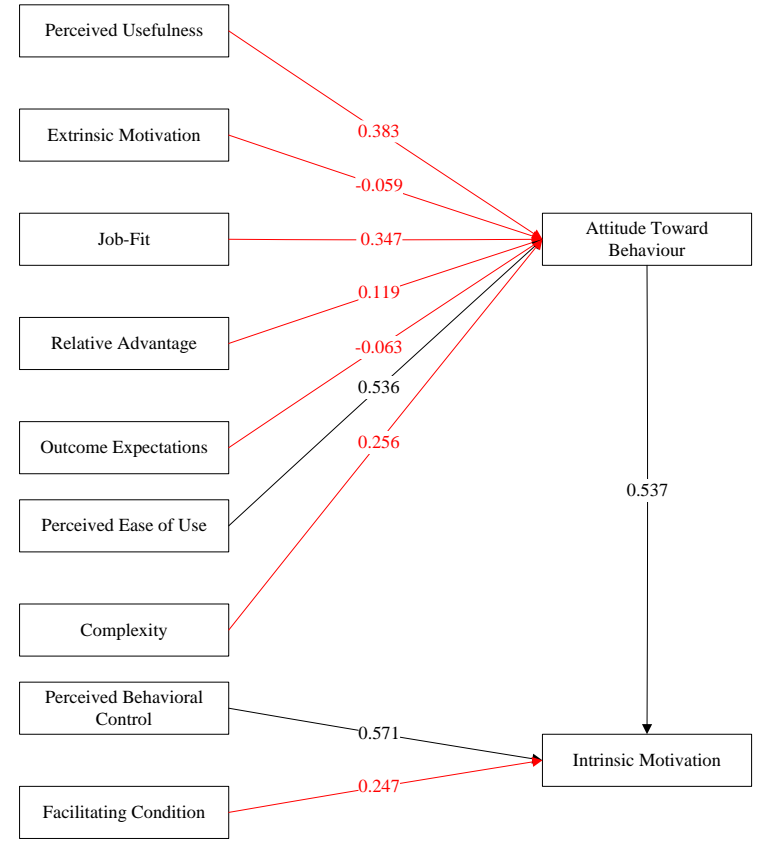

Gambar 11. Hasil Model analisa

\section{KESIMPULAN DAN SARAN}

Kesimpulan

1. Dari hasil analisis empiris yang dilakukan terdapat delapan faktor yang berpengaruh terhadap penerimaan teknologi pada PTIIK-UB. Faktor-faktor yang berpengaruh terhadap penerimaan e-learning di blended learning adalah:

H1: PU, JF, RF, EA dan OE kurang mempengaruhi faktor AT

$\mathrm{H} 2$ : PEoU mempengaruhi faktor AT sedangkan variable complexity kurang mempengaruhi H3: SN, SF, dan I kurang memberikan kontribusi pada ATH4: PB mempengaruhi faktor AT sedangkan variable FC kurang mempengaruhi H5 : AT mempengaruhi IM

2. Dosen lebih memilih sistem lain seperti blog dosen dan dropbox karena beranggapan unjuk kerja dari e-learning kurang maksimal dan tidak memberikan dampak yang signifikan terhadap kemudahan dalam proses belajar mengajar.

3. Menggunakan e-learning dosen-dosen percaya tidak akan meningkatkan image terhadap rekan sejawatnya serta faktor sosial seperti keberadaan rekan-rekan yang menggunakan e-learning tidak serta merta membuat rekan dosen yang lain menggunakan sistem ini.

4. E-learning tidak terintegrasi dengan sistem yang ada di PTIIK UB seperti SIAM dan SIADO. Hal ini menyebabkan motivasi dalam menggunakan elearning menurun.

\section{Saran}

1. Perlu adanya perbaikan fitur-fitur dari elearning tanpa meninggalkan sisi kemudahan bagi pengguna. Banyak diantara responden lebih memilih menggunakan media lain untuk mendukung proses pembelajaran dengan blended learning.

2. Perlu adanya pemuktahiran model agar parameter dan hasil pengukuran dapat lebih maksimal.

\section{DAFTAR PUSTAKA}

Dasgupta, S., Granger, M. \& Mcgarry, N.,'User acceptance of e-collaboration technology: an extension of the technology acceptance model'. 2002. Group Decision and Negotiation, 11, 87100. Kluwer Academics Publishers.

Davis, F.D., "Perceived usefulness, perceived ease of use and user acceptance of information technology". 1989. MIS Quarterly, 13(3), 319339.Management Information System Research Center, University of Minnesota.

Bachtiar, F.dkk. "Acceptance in the Deployment of Blended Learning as a Learning Resource in Information Technology and Computer Science Program". 2013. Apcase.

Graham, C. R.\& Bonk, C.J. "Blended learning systems: Definition, current trends, and future directions". 2006. In C. J. Bonk \& C. R. Graham (Eds.), The handbook of blended learning: global perspectives, local designs. San Fransisco, CA: Pfeiffer Publishing, 3-21.

Keller, C., Hrastinski, S., \& Carlsson, S.A., 'Students' Acceptance of E-learning Environments: A Comparative Study in Sweden and Lithuania". 2007. In Proceedings of the 15th European Conference on Information Systems, June 7-9, St. Gallen, Switzerland, 395-406.

Masrom, M., "Technology Acceptance Model and ELearning”. 2007. 12th International Conference on Education, Sultan Hassanal Bolkiah Institue of Education, University Brunei Darussalam 21-24 May 2007.

Oh, E., and Park, S., "How are universities involved in blended instruction". 2009. Educational Technology and Society, 12 (3), 327-342.

Park, S.Y., "An Analysis of the Technology Acceptance Model in Understanding University Studnets' Behavioral Intention to Use eLearning”. 2009. Educational Technology \& Soeciety, 12(3), $150-162$.

Pituch, K.A., Lee, Y. "The influence of system characteristics on e-learning use". 2004. Computers \& Education 47 (2006) 222244.Elsevier.

Venkatesh, et all. User Acceptance of information Technology : Toward a Unified View”. 2003. MIS Quarterly Vol. 27 No. 3, pp. 425-478. 